\title{
Reduced Erythrocyte Superoxide Dismutase Activity in Low Birth Weight Infants Given Iron Supplements
}

\author{
S. M. BARCLAY, P. J. AGGETT, D. J. LLOYD, AND P. DUFFTY \\ Department of Child Health, University of Aberdeen, Scotland, United Kingdom
}

\begin{abstract}
Erythrocyte superoxide dismutase (ESOD) activity reflects copper utilization and the risk of copper deficiency. To investigate the possible effects of inorganic iron on the metabolism of copper in low birth weight infants, we have measured ESOD activities in three groups of infants receiving different iron supplements. Fifty-five low birth weight infants were randomly assigned to receive daily from $28 \mathrm{~d}$ either $13.8 \mathrm{mg}$ (HiFe), $7 \mathrm{mg}$ (MidFe), or no elemental iron (NatFe) as iron edetate. At $27 \mathrm{~d}, 8,12$, and 20 wk postnatal age, infants were weighed and measured and hematologic indices, plasma ferritin, zinc, and copper concentrations, and ESOD activities were assayed. Anthropometrical and hematologic indices and plasma copper and zinc concentrations did not differ among treatment groups at any time, but at $\mathbf{2 0} \mathbf{w k}$, plasma ferritin concentrations $[(\mu \mathrm{g} / \mathrm{L})$ mean; $\mathrm{SD}]$ were lower in the NatFe group $(17 ; 2.0)$ than in the HiFe group $(32 ; 1.9: 95 \%$ confidence interval for mean difference 6.6 to $22.0, \mathrm{p}<0.01$ ). ESOD activities $(\mathrm{U} / \mathrm{g} \mathrm{Hb})$ were similar in $\mathrm{HiFe}(1447 ; 263)$, MidFe $(1552 ; 322)$, and NatFe $(1538 ; 382)$ groups at 27 d, but by 20 wk activities in the HiFe group $(1537 ; 211)$ were lower than in the MidFe $(1789 ; 403: 95 \%$ confidence interval 38 to $466, p<0.05)$ and NatFe $(1858 ; 304: 95 \%$ confidence interval 150 to $492, p<0.01$ ) groups. The lower ESOD activities found in the $\mathrm{HiFe}$ group at 20 wk may reflect altered copper metabolism induced by the iron supplement, but the clinical importance of this observation is unknown. (Pediatr Res 29: 297-301, 1991)
\end{abstract}

\section{Abbreviations}

ESOD, erythrocyte superoxide dismutase

CI, confidence interval

HiFe, high iron intake

LBW, low birth weight

MidFe, middle iron intake

NatFe, natural iron intake

SOD, superoxide dismutase

RBC, red blood cell

\footnotetext{
Because iron and copper have similar physicochemical properties, interactions can occur between them that can affect adversely the metabolism of copper (1). The practical relevance of this has been shown in mixed fed healthy infants in whom an iron-fortified $(10.2 \mathrm{mg} / \mathrm{L})$ formula achieved a lower intestinal absorption and whole body retention of copper than did the

Received February 21, 1990; accepted October 24, 1990.

Correspondence and reprints: Dr. S. Barclay, Department of Child Health, University of Aberdeen, Polwarth Building. Foresterhill, Aberdeen AB9 2ZD, UK

Supported by Nutricia (Netheriands), Grampian Health Board Medical Endowments Funds and The Aberdeen Special Nursery Fund.
}

same formula with no added iron $(2.5 \mathrm{mg} / \mathrm{L})(2)$. Such an interaction could be important in preterm and LBW infants who are at an increased risk of copper deficiency $(3,4)$ because these babies are often given generous supplements of iron in addition to that included in their formulas (5). Although plasma copper concentrations in such infants have been shown to be unaffected by iron supplementation (6), neither plasma concentrations of copper nor of ceruloplasmin reflect accurately any early risk of impaired copper utilization or copper deficiency (7). The activity of the cupro-zinc metalloenzyme SOD (EC 1.15.1.1) in erythrocytes has been found in animal models $(8,9)$ and human volunteers $(10-12)$ to be a more sensitive indicator of potential copper deficiency or of an altered metabolism of copper, such as that secondary to interactions with zinc and iron $(10,13)$

We have therefore monitored the ESOD activity of LBW infants to investigate the possibility that iron supplements may alter their systemic metabolism of copper; additionally, plasma zinc and ferritin concentrations were measured.

\section{SUBJECTS AND METHODS}

Sixty-two LBW infants (birth weight less than $2500 \mathrm{~g}$ ), were recruited, and 55 completed the study. Exclusion criteria were congenital or chromosomal abnormalities, hemolytic disease, gastrointestinal problems, i.v. feeding for more than $5 \mathrm{~d}$, and blood transfusion after $14 \mathrm{~d}$ of age. Informed parental consent was obtained and the study was approved by the Joint Ethical Committee of The Grampian Area Health Board and the University of Aberdeen.

The gestational ages of the infants were assessed from maternal menstrual history or biparietal diameter by ultrasound scan and from physical criteria (14). The babies were then assigned randomly within three strata based on gestational age ( $<32 \mathrm{wk}, 33-$ $35 \mathrm{wk}$, and $>36 \mathrm{wk}$ ) to receive daily from $28 \mathrm{~d}$ of age, as sodium iron edetate, either $13.8 \mathrm{mg}$ (HiFe), $7 \mathrm{mg}$ (MidFe), or no elemental iron (NatFe) in addition to their "natural" or dietary intakes (Table 1). These dosages reflect the range of iron dosages currently prescribed in U.K. neonatal units (5). Twins were always allocated to different treatment groups. The liquid iron preparation was administered by oral syringe between feeds. Infants of less than $33 \mathrm{wk}$ gestation were all appropriately grown for gestational age, whereas those older than $35 \mathrm{wk}$ gestation were light for dates. The intermediate gestational age-group contained infants in both categories. The absolute values and SD scores for birthweight, crown-heel length, and head circumference of the treatment groups were similar.

Eleven infants (four, four, and three, respectively, from the $\mathrm{HiFe}$, MidFe, and NatFe groups) received their own mother's breast milk throughout the study. The remaining infants received, where appropriate, initially a preterm formula followed by cows' milk-based infant formulas, all of which contained 5$6.7 \mathrm{mg}$ of inorganic $\mathrm{Fe} / \mathrm{L}$. Although the formulas were not "ironfortified," relatively high iron intakes were achieved (Table 2) 
because of the volumes of feed administered (up to $200 \mathrm{~mL} / \mathrm{kg}$ / d). No infant received solids until the last $2 \mathrm{wk}$ of the study when the mothers of 15 (five, four, and six from the HiFe, MidFe, and NatFe groups, respectively) had started to introduce an occasional spoonful of a rice-based weaning product. From $14 \mathrm{~d}$ postnatal age, infants received a multivitamin preparation (0.6 mL Abidec; Warner Lambert, Eastleigh, Hampshire, UK) providing $50 \mathrm{mg}$ of ascorbic acid either once or twice daily; infants of birth weight less than $1750 \mathrm{~g}$ were also given $1 \mathrm{mg}$ folic acid once daily. In addition, infants of less than $1500 \mathrm{~g}$ at birth and those of less than 33 wk gestation received vitamin E $[20 \mathrm{mg} / \mathrm{kg}$ intramuscularly (Hoffman-La Roche \& Co. AG, Basel, Switzerland) daily for $3 \mathrm{~d}$, followed by $5 \mathrm{mg} / \mathrm{kg}$ daily orally (Roche, Welwyn Gardens City, England)] until they reached 34 wk postconceptional age.

The infants were reviewed on entry into the study at $27 \mathrm{~d}$, and thereafter at 8,12, and $20 \mathrm{wk}$ postnatal age. At each review, enough of the iron and vitamin preparations were supplied to last until the next visit and the mothers were instructed in their dosage and administration. Additionally at each visit, the dietary

Table 1. Composition of treatment groups completing the study

\begin{tabular}{cccccc}
\hline $\begin{array}{c}\text { Iron } \\
\text { supplement } \\
(\mathrm{mg} / \mathrm{d})\end{array}$ & $<32$ & $33-35$ & $>36$ & Total & $\begin{array}{c}\text { Birth wt } \\
(\mathrm{g})^{*}\end{array}$ \\
\cline { 2 - 5 } & $<$ & 11 & 3 & 20 & $1937 ; 356$ \\
13.8 & 6 & 7 & 5 & 16 & $1921 ; 308$ \\
7.0 & 4 & 9 & 6 & 19 & $2016 ; 331$ \\
\hline
\end{tabular}

* Mean; SD.

Table 2. Estimated daily intakes of iron, zinc, and copper (formula-fed infants only) $(U / \mathrm{kg} / \mathrm{d})$ (mean; $S D)$

\begin{tabular}{ccccc}
\hline \multirow{2}{*}{$\begin{array}{c}\text { Postnatal } \\
\text { age }(w \mathrm{wk})\end{array}$} & $\begin{array}{c}\text { Iron } \\
\text { supplements } \\
(\mathrm{mg} / \mathrm{d})\end{array}$ & Iron $(\mathrm{mg})$ & Zinc $(\mathrm{mg})$ & Copper $(\mu \mathrm{g})$ \\
\hline \multirow{3}{*}{4} & 13.8 & $6.8 ; 0.3$ & $0.8 ; 0.1$ & $110 ; 14$ \\
& 7 & $4.2 ; 0.4$ & $0.8 ; 0.2$ & $110 ; 32$ \\
& 0 & $1.6 ; 0.3$ & $0.9 ; 0.1$ & $118 ; 22$ \\
20 & 13.8 & $3.6 ; 0.2$ & $0.6 ; 0.1$ & $69 ; 18$ \\
& 7 & $1.8 ; 0.2$ & $0.5 ; 0.1$ & $73 ; 16$ \\
& 0 & $1.0 ; 0.3$ & $0.6 ; 0.1$ & $75 ; 15$ \\
\hline
\end{tabular}

Table 3. Mean $\mathrm{Hb}$ concentration $(\mathrm{g} / \mathrm{L})$ in observed infants (mean and $95 \%$ CI)

\begin{tabular}{ccccc}
\hline \multirow{2}{*}{$\begin{array}{c}\text { Iron } \\
\text { supplements } \\
(\mathrm{mg} / \mathrm{d})\end{array}$} & \multicolumn{4}{c}{ Postnatal age (wk) } \\
\cline { 2 - 5 } & 4 & 8 & 12 & 20 \\
\hline 13.8 & 119 & 96 & 106 & 117 \\
$(n=20)$ & $(112-127)$ & $(92-100)$ & $(101-111)$ & $(111-123)$ \\
7 & 114 & 96 & 101 & 115 \\
$(n=16)$ & $(100-127)$ & $(89-103)$ & $(95-107)$ & $(107-123)$ \\
0 & 114 & 96 & 104 & 112 \\
$(n=19)$ & $(104-125)$ & $(91-104)$ & $(100-108)$ & $(107-118)$ \\
\hline
\end{tabular}

Table 4. Plasma ferritin concentrations $(\mu \mathrm{g} / \mathrm{L})$ (mean and $95 \% \mathrm{CI}$ )

\begin{tabular}{ccccc}
\hline \multirow{2}{*}{$\begin{array}{c}\text { Iron } \\
\text { supplement } \\
\text { (mg/d) }\end{array}$} & 4 & 8 & 12 & 20 \\
\cline { 2 - 5 } & 182 & 109 & 62 & $32^{*}$ \\
\hline 13.8 & $(129-258)$ & $(74-160)$ & $(42-91)$ & $(24-44)$ \\
& 130 & 75 & 41 & 23 \\
7 & $(79-212)$ & $(47-119)$ & $(29-58)$ & $(17-31)$ \\
& 129 & 71 & 40 & $17^{*}$ \\
0 & $(89-189)$ & $(47-107)$ & $(27-58)$ & $(12-24)$ \\
\hline
\end{tabular}

${ }^{*} p<0.01$
Table 5. Plasma copper concentrations ( $\mu$ mol/L) by gestational age (mean and $95 \% \mathrm{CI}$ )

\begin{tabular}{ccccc}
\hline & \multicolumn{4}{c}{ Postnatal age (wk)* } \\
\cline { 2 - 5 } & 4 & 8 & 12 & 20 \\
\hline Gestation (wk) & & & & \\
$<32(n=14)$ & $5.6^{a}$ & 8.5 & 9.5 & $10.7^{a . b}$ \\
& $(4.3-6.8)$ & $(6.5-10.6)$ & $(7.7-11.3)$ & $(9.3-12.1)$ \\
$33-35(n=28)$ & 6.7 & 9.5 & 11.7 & $13.3^{a}$ \\
& $(5.7-7.6)$ & $(8.5-10.4)$ & $(10.5-12.9)$ & $(12.0-14.6)$ \\
$>36(n=13)$ & $8.5^{a}$ & 10.2 & 11.9 & $14.5^{b}$ \\
& $(6.7-10.3)$ & $(8.8-11.5)$ & $(10.3-13.6)$ & $12.7-16.3)$ \\
\hline
\end{tabular}

* At each postnatal age, statistically significant differences between values bearing the same superscript are as follows: ${ }^{a} p<0.01 ;^{b} p<0.001$.

history was reviewed. Intakes of iron, zinc, and copper were estimated for the formula-fed infants using declared compositions and analyzed values of the formulas. The elemental intakes of breast-fed infants could not be estimated. Any feeding difficulties, intercurrent illnesses, or hospital admissions were recorded.

Weight (model 727, electronic scales, Seca, Hamburg, Germany), crown-heel length (Infantometer; Holtain Ltd., Crymych, Dyfed, UK), and occipito-frontal circumference were measured at each visit by the same observer and $2-2.5 \mathrm{~mL}$ of venous blood was taken and transferred immediately to a NaEDTA tube for hematologic analysis and to a deionized lithium-heparin tube for plasma copper, zinc, and ferritin and ESOD analyses. The heparinized sample was centrifuged at $1000 \times g$ for 10 min within $1 \mathrm{~h}$ of collection and the plasma removed and stored at $-20^{\circ} \mathrm{C}$ until analysis; the cells were washed twice with isotonic $0.9 \%$ saline before being similarly stored.

Analyses. SD scores for weight, length, and occipito-frontal circumference were calculated from reference charts (15).

$\mathrm{Hb}$ concentration and red-cell indices were measured by Coulter counter and a blood film was examined by a hematologist if these indices were abnormal; reticulocyte counts were measured if the $\mathrm{Hb}$ was below $100 \mathrm{~g} / \mathrm{L}$.

Plasma copper and zinc concentrations were determined by atomic absorption spectrophotometry (model no. SP 9, Pye Unicam, Cambridge, England) after dilution in $6 \%$ acid-washed butanol (16), and plasma ferritin concentration by RIA (Behring RIA-gnost, Hounslow, Middlesex, UK).

ESOD was assayed by the method of Jones and Suttle (17). In brief, the blood cells were lysed by repeated freezing and thawing and centrifuged at $3000 \times g$ for $10 \mathrm{~min}$ to separate the cell membranes. ESOD activity in the lysate supernatant was assayed, after a 500 -fold dilution in $0.01 \mathrm{M}$ phosphate buffer, by determining the ability of the supernatant to inhibit the oxidation of iodonitrotetrazolium violet by superoxide generated by the aerobic oxidation of xanthine by xanthine oxidase (both by Sigma Diagnostics, Poole, Dorset, UK). SOD activities were calibrated against purified ESOD (Sigma Diagnostics), which had an activity of $3150 \mathrm{U} / \mathrm{mg}$ protein as defined by McCord and Fridovich (18) and are expressed in $\mathrm{U} / \mathrm{g} \mathrm{Hb}$; to compensate for falling mean corpuscular volume, activities were also calculated per individual erythrocyte (U/RBC). The interbatch and intrabatch coefficient of variation for this assay was $6.5 \%$.

There are two SOD isoenzymes in eukaryotic cells: a cytoplasmic cuprozinc form (CuZn SOD) that depends on copper for its catalytic activity with zinc as an important structural component and a manganese-dependent mitochondrial form. Because cyanide inhibits cupro-enzymes but not mangano-enzymes, the respective contributions of these two enzymes to the total SOD activity was explored by measuring SOD activities in the absence and presence of $2 \mathrm{mM}$ cyanide. All activity was cyanide-sensitive and could therefore be attributed to $\mathrm{CuZn}$ SOD, the vast majority of which is located within erythrocytes.

$\mathrm{The} \mathrm{Hb}$ concentration of the lysate was determined from the 


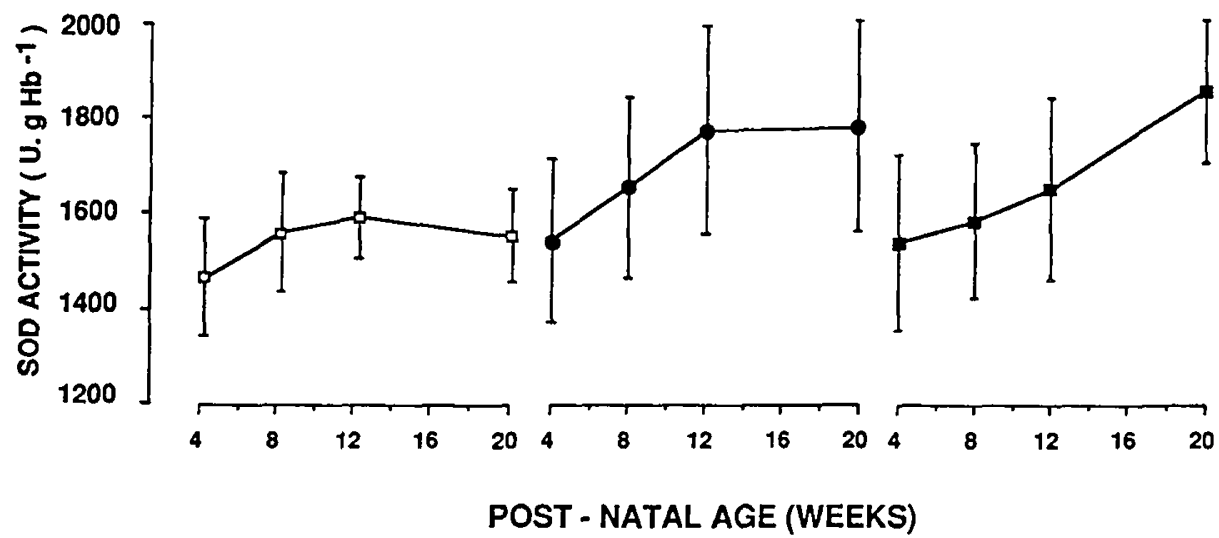

Fig. 1. CuZn SOD activities/g of $\mathrm{Hb}$ (mean and $95 \% \mathrm{CI}$ ) in infants receiving daily $13.8 \mathrm{mg}(\square), 7 \mathrm{mg}(\bullet)$, or no ( $\square$ ) additional elemental iron.

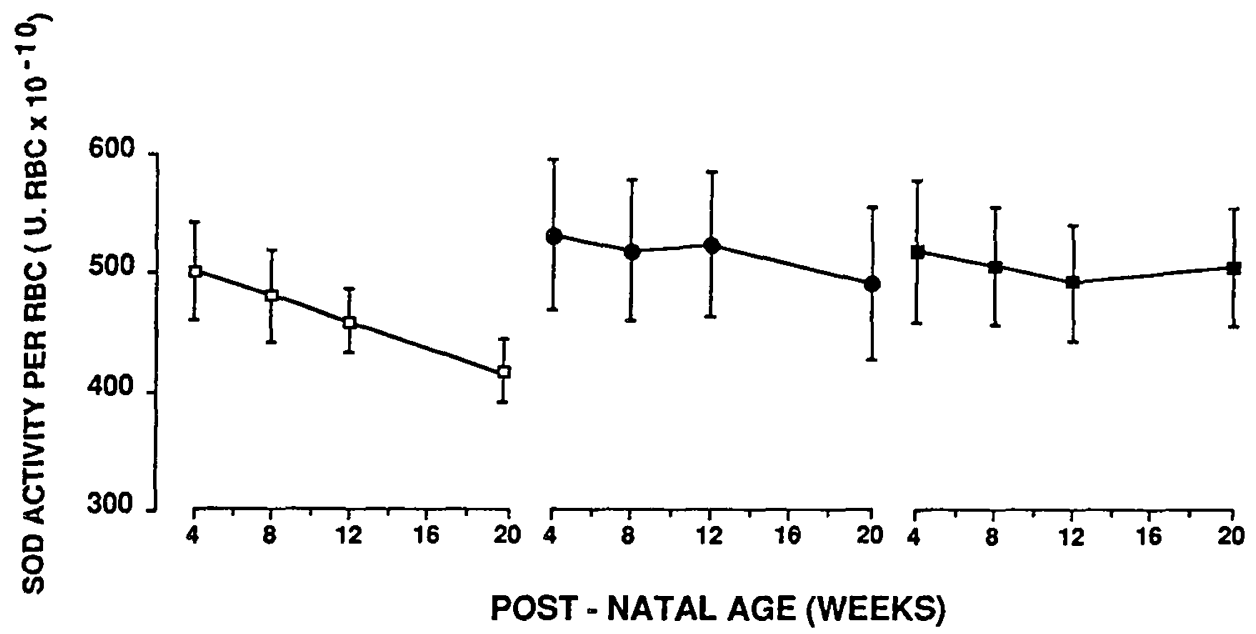

Fig. 2. CuZn SOD activities/RBC (mean and $95 \% \mathrm{CI}$ ) in infants receiving daily $13.8 \mathrm{mg}(\square), 7 \mathrm{mg}(\bullet)$, or no (ロ) additional elemental iron.

optical density of cyanohemoglobin at $540 \mathrm{~nm}$ (Sigma Diagnostics).

Statistical analyses. At each postnatal age, differences in observed values among gestational age groups and among treatments for the combined gestation groups were analyzed by oneway analysis of variance (Minitab Inc., University Park, PA). Where appropriate, specific differences were evaluated by unpaired $t$ tests (19). Plasma ferritin data were compared after normalization of the results by logarithmic transformation.

\section{RESULTS}

Fifty-five infants completed the study (Table 1). Data from seven recruited infants, six of whom failed to attend all reviews and one who did not tolerate the iron supplement, are not reported here. No child became seriously ill during the study and the rate of minor infections or gastrointestinal upsets did not differ among the groups. All infants grew normally throughout the study and there were no differences among treatment groups in any of the growth parameters measured.

Whereas the iron intakes of the NatFe group averaged 4-fold less than that of the HiFe and 2.5-fold less than that of the MidFe groups, zinc and copper intakes were similar in all treatment groups throughout the study (Table 2 ). Hb concentrations and mean corpuscular volume did not differ significantly among treatment groups (Table 3 ) and both the absolute values and the trends with increasing age were consistent with earlier observations (20). Neither were there any significant intergroup differences in reticulocyte counts, total and differential white cell counts, or platelet counts.

Gestational age or the type of feed (breast milk or formula) did not affect any of the growth or hematologic parameters.
There was great interindividual variation in plasma ferritin concentrations (Table 4) with considerable overlap among treatment groups until 20 wk postnatal age when values in the $\mathrm{HiFe}$ group infants (mean, SD; 32, $1.9 \mu \mathrm{g} / \mathrm{L}$ ) were higher than those of the NatFe group $(17,2.0 \mu \mathrm{g} / \mathrm{L} ; 95 \% \mathrm{CI}$ for difference between means 6.6 to $22.0 \mu \mathrm{g} / \mathrm{L} ; p<0.01)$. Ferritin concentrations in the MidFe group did not differ $(p>0.05)$ from the other two groups at any time. By 20 wk postnatal age, two infants in the unsupplemented group and one infant in the MidFe group had plasma ferritin concentrations less than $10 \mu \mathrm{g} / \mathrm{L}$ and thus could be considered to have been iron-depleted. Neither these nor any other infant had any hematologic evidence of iron deficiency.

Plasma copper levels increased with postnatal age in all the treatment groups and there were no differences among the treatment groups or among the individual gestational age strata. Because iron treatment did not affect plasma copper levels, the influence of gestational age was investigated by combining the results of the three gestational age strata (Table 5). The plasma copper concentrations of the most preterm infants were significantly lower than those of the most mature infants at $4 \mathrm{wk}$ and both of the older groups at $20 \mathrm{wk}$ postnatal age. At the end of the study, the plasma copper concentrations of the 11 infants receiving breast milk $(10.6 \mu \mathrm{mol} / \mathrm{L}$; SD 1.0$)$ were significantly lower than those of the 44 formula-fed infants $(13.5 \mu \mathrm{mol} / \mathrm{L} ; \mathrm{SD}$ 3.3; $95 \% \mathrm{CI}$ for mean difference 0.53 to $5.27, p<0.001$ ).

At each visit and with each treatment group, there was a wide range of plasma zinc levels and no trend with increasing maturity or postnatal age was seen (data not shown). Neither gestational age nor iron treatment had any significant effect upon plasma zinc concentrations. At $4 \mathrm{wk}$ postnatal age, the plasma zinc concentrations of the infants receiving breast milk $(n=11 ; 14.4$ 
$\mu \mathrm{mol} / \mathrm{L}$; SD 3.1) were higher than those of the formula-fed infants $(n=44 ; 11.1 \mu \mathrm{mol} / \mathrm{L} ; \mathrm{SD} 2.7 ; 95 \% \mathrm{CI}$ for mean difference 1.1 to $5.5, p=0.02$ ), but there were no differences at later ages.

When ESOD activities were expressed as $\mathrm{U} / \mathrm{g} \mathrm{Hb}$ (Fig. 1), activities were similar in all treatment groups at $4 \mathrm{wk}$ postnatal age; thereafter, ESOD activity remained fairly constant in the HiFe group whereas in the other two groups it rose steadily. As a result, at 20 wk postnatal age, activities in the HiFe group (1537 U/g Hb, SD 211) were lower than in the MidFe (1789 U/ $\mathrm{g} \mathrm{Hb}, \mathrm{SD} 403 ; 95 \% \mathrm{CI}$ for difference between means 38 to 466 , $p<0.05)$ and NatFe groups (1858 U/g Hb, SD 304; $95 \% \mathrm{CI}$ for mean difference 150 to $492, p<0.01)$.

When expressed per red cell, ESOD activities in the $\mathrm{HiFe}$ group declined steadily throughout the study, whereas in the other two groups they remained relatively constant (Fig. 2). At $20 \mathrm{wk}$, activities in the HiFe group $\left(419 \mathrm{U} / \mathrm{RBC} \times 10^{10}, \mathrm{SD}\right.$ 54.0) were again lower than in the MidFe (495 U/RBC $\times 10^{10}$, SD $116 ; 95 \% \mathrm{CI}$ for mean difference 4.6 to $70.6, p<0.05$ ) and NatFe groups $\left(506 \mathrm{U} / \mathrm{RBC} \times 10^{10} \mathrm{SD} 101 ; 95 \% \mathrm{CI}\right.$ for mean difference 10 to $114, p<=0.01$ ). These statistically significant differences in ESOD activities persisted when the data were reanalyzed after excluding the infants with plasma ferritin concentrations below $10 \mu \mathrm{g} / \mathrm{L}$ or those who had been breast fed.

When ESOD activity was considered as a function of postconceptional age rather than as a function of postnatal age, the differences in activity among treatment groups described above were still evident, as was each group's change in activity with time. To avoid any possible bias from term light-for-date infants, the results were reanalyzed after exclusion of data from infants of greater than $35 \mathrm{wk}$ gestation; the differences among treatment groups at $20 \mathrm{wk}$ postnatal age were still evident ( $\mathrm{HiFe} n=17$, $1525 \mathrm{U} / \mathrm{g} \mathrm{Hb}$, SD 215; NatFe $n=12,1806 \mathrm{U} / \mathrm{g} \mathrm{Hb}$, SD 351; $95 \%$ CI 39 to $522, p<0.05$ ).

\section{DISCUSSION}

The principal finding of this study was that the higher intake of iron was associated at 20 wk postnatal age with lower ESOD activities than in the other two groups. The iron supplement, however, did not have any effect upon other indices of copper metabolism, plasma zinc concentrations, weight gain, linear growth, hematologic indices, or rates of infection.

The values and pattern of plasma ferritin concentrations reported here are consistent with other studies of iron supplementation in preterm and LBW infants (21) and suggest that some additional iron is necessary to prevent iron deficiency. However, the values are lower than those of Halliday et al. (22), who found no difference between supplemented and unsupplemented infants whose characteristics and iron intakes $(0.5-5.4 \mathrm{mg} / \mathrm{kg} / \mathrm{d})$ were similar to those in this study.

Although iron interferes with the intestinal absorption and systemic metabolism of zinc (23), the iron supplements used in this study had no effect on plasma zinc concentrations; this, however, gives no real indication of the relative risks of zinc deficiency in these treatment groups. The plasma zinc concentrations here are comparable to those previously described $(6$, 24-26). It was interesting that we noted a higher plasma zinc concentration in breast-fed infants at $4 \mathrm{wk}$ of age compared with those fed formulas. This difference was not seen at later stages; a similar difference with feeding has been seen in term infants at 6 mo of age (27), although with that study the $\mathrm{Zn}$ content of the formula was about half that of the formulas used in this study.

Plasma copper concentrations were within reported ranges and, similarly, showed the reported increase with postnatal age $(6,28,29)$. However, whereas plasma copper concentrations were not affected by iron supplementation, ESOD activity was.

There are no extensive data on ESOD activity in early infancy. A prolonged longitudinal study (30) of preterm LBW infants of varying postconceptional age reports relatively constant activities per RBC until 10 wk postnatal age. However, these infants received daily from the 4 th wk of life $30 \mathrm{mg}$ of elemental iron, more than twice that supplied to the HiFe infants in this study; even so, the reported activities were approximately twice those reported here. Methodologic differences may have contributed to this disparity and to the contrasting results of several crosssectional studies in which ESOD activities fell (31), remained constant $(32,33)$, or rose $(34,35)$ with increasing postconceptional age. This preliminary report provides the first data on $\mathrm{LBW} /$ preterm infants followed until 20 wk postnatal age, and on such infants who have not received iron supplements.

Because erythrocytes do not synthesize protein, the appearance of any change in ESOD activity would be gradual and would depend on the rate of erythrocyte turnover. Thus, it is not surprising that the differences in activities among treatment groups were not apparent until the end of the study, although the size of the iron supplement relative to body weight had by then fallen. The gradual decline in ESOD activity seen here in the HiFe group would be consistent with reduced SOD activity in newly produced red cells.

The precise cause of the difference in ESOD activities among treatment groups at $20 \mathrm{wk}$ postnatal age in this study is not known. Apart from some genetic disorders, leukemias, and lymphoproliferative disorders (36), the only known cause of reduced ESOD activity is copper depletion, and in studies of copperdepleted adults $(11,12)$ or those receiving zinc supplements $(10$, 13) a reduction of ESOD activity was the earliest indicator of disturbed copper metabolism. Although high doses of ascorbic acid can alter the metabolism of copper in rats (37) and adult men $(38,39)$, the doses of ascorbate used in this study were similar in all treatment groups. Similarly, solids contributed only a small amount to the dietary intake of 15 infants and would take longer than 2 wk to have any effect on ESOD activity. We suspect that the association of lower ESOD activities with the higher dose of iron supplement represents an impairment of copper utilization induced by the iron. We are currently repeating the study to determine whether copper supplements can prevent or reverse the changes in ESOD activity.

The alternative explanation, that the differences in ESOD activity arise from an unusual increase in activities in the MidFe and NatFe groups by 20 wk postnatal age, seems unlikely. Increased ESOD activity has been described in animal models only with extreme oxidant stress (40) or severe iron deficiency anemia $(41)$ or in humans with Down's syndrome $(42,43)$ or uremia (44), none of which applied in this study.

We do not know the clinical significance of the observed reduction in ESOD activities in the HiFe group. The levels of ESOD activity found here are higher than those found in hypocupremic children recovering from malnutrition $(864 \mathrm{U} / \mathrm{g} \mathrm{Hb}$, SD 213) (45) or convalescent malnourished normocupremic toddlers (1073 U/g Hb, SD 312) but are similar to those present after copper repletion and in a copper-replete reference group (1461 U/g Hb, SD 451) (46). Thus, it is unclear whether the lower ESOD activities of the HiFe group represent an increased risk of oxidant damage or of a systemic functional copper deficiency. Nonetheless it seems important to consider such an effect of iron on the metabolism of copper when planning the amount of iron supplements for infants especially when, as with the case of LBW infants, there is a risk of copper deficiency.

Acknowledgments. The authors thank the Neonatal Nursing Staff and Kay Harrold for their help and support.

\section{REFERENCES}

1. Mills CF 1985 Dietary interactions involving the trace elements. Ann Rev Nutr 5:173-193

2. Haschke F, Ziegler EE, Edwards BB, Fomon SJ 1986 Effects of iron fortification of infant formula on trace mineral absorption. J Ped Gastroenterol Nutr 5:768-773

3. Anonymous 1987 Copper and the infant. Lancet 1:900-901

4. Shaw JCL 1988 Copper deficiency and non-accidental injury. Arch Dis Child 63:448-455 
5. Barclay SM, Lloyd DJ, Duffty P, Aggett PJ 1989 Iron supplements for preterm or low birthweight infants. Arch Dis Child 64:1621-1622

6. McMaster D, Lappin TRJ, Halliday HL, Patterson CC 1983 Serum copper and zinc levels in the preterm infant (a longitudinal study of the first year of life). Biol Neonate 44:108-113

7. Solomons NW 1979 On the assessment of zinc and copper nutriture in man. Am J Clin Nutr 32:856-871

8. Bohnenkamp W, Weser U 1976 Copper deficiency and erythrocuprein (2Cu, 2Zn-superoxide dismutase). Biochim Biophys Acta 444:396-406

9. Paynter DI, Moir RJ, Underwood EJ 1979 Changes in the activity of the Cu$\mathrm{Zn}$ superoxide dismutase enzyme in tissues of the rat with changes in dietary copper. J Nutr 109:1570-1576

10. Samman S, Roberts DCK 1988 The effect of zinc supplements on lipoproteins and copper status. Atherosclerosis 70:247-252

11. Reiser S, Smith JC, Mertz W, Holbrook JT, Scholfield DJ, Powell AS, Canfield WK, Corary JJ 1985 Indices of copper status in humans consuming a typical American diet containing either fructose or starch. Am J Clin Nutr 42:242251

12. Klevay LM, Inman L, Johnson LK, Lawler M, Mahalko JR, Milne DB, Lukoski HC, Bolonchuk W, Sanstead HH 1984 Increased cholesterol in plasma in a young man during experimental copper depletion. Metabolism 33:1112-1118

13. Yadrick MK, Kenney MA, Winterfeldt EA 1989 Iron, copper and zinc status: response to supplementation with zinc or zinc and iron in adult females. Am J Clin Nutr 49:145-150

14. Farr V, Kerridge DF, Mitchell RG 1966 The value of some external characteristics in the assessment of gestational age at birth. Develop Med Child Neurol 8:657-660

15. Gairdner D, Pearson J 1988 Growth and Development Record: Preterm-2 Years. Length/Weight/Head Circumference. Castlemead Publications Ref. GPB3 Integrated Series. Ware. Herts, UK

16. Meret S, Henkin RI 197 I Simultaneous direct estimation by atomic absorption spectrophotometry of copper and zinc in serum, urine and cerebrospinal fluid. Clin Chem 17:369-373

17. Jones DG, Suttle NF 1981 Some effects of copper deficiency on leucocyte function in sheep and cattle. Res Vet Sci 31:151-156

18. McCord JM, Fridovich I 1969 Superoxide dismutase; an enzymic function for erythrocuprein (hemocuprein). J Biol Chem 244:6049-6055

19. Snedecor GW, Cochran WG 1980 Statistical Methods, 7th Ed. Iowa State University Press, Ames, lowa

20. Lundstrom U, Siimes MA 1980 Red blood cell values in low-birth-weight infants: ages at which values become equivalent to those of term infants. J Pediatr 96:1040-1042

21. Lundstrom U, Siimes MA, Dallman PR 1977 At what age does iron supplementation become necessary in LBW infants? J Pediatr 91:878-883

22. Halliday HL, Lappin TRJ, McClure BG 1983 Do all preterm infants need iron supplements? Ir Med J 72:695-698

23. Solomons NW 1986 Competitive interaction of iron and zinc in the diet: consequences for human nutrition. J Nutr 116:927-935

24. Gibson RS, Dewolfe MS 1981 Changes in serum zinc concentrations of some Canadian full-term and low birthweight infants from birth to six months. Acta Paediatr Scan 70:497-500

25. Tyrala EE, Manser JI, Brodsky NL, Tran N 1983 Serum zinc concentrations in growing premature infants. Acta Paediatr Scand 72:695-698

26. Haschke F, Singer P, Baumgartner D, Steffan I, Schilling R, Lothaller H 1985 Growth, zinc and copper nutritional status of male premature infants with different zinc intake. Ann Nutr Metab 29:95-102
27. Hambidge KM, Walravens PA, Casey CE, Brown RM, Bender C 1979 Plasma zinc concentrations of breast-fed infants. J Pediatr 94:607-608

28. Hillman LS 1981 Serial serum copper concentrations in premature and SGA infants during the first three months of life. J Pediatr 98:305-308

29. Sutton AM, Harvie A, Cockburn F, Farquharson J, Logan RW 1985 Copper deficiency in the preterm infant of very low birthweight. Arch Dis Child 60:644-651

30. Haga P 1981 Caeruloplasmin levels and erythrocyte superoxide dismutase activity in small preterm infants during the early anaemia of prematurity. Acta Paediatr Scand 70:861-864

31. Bonta BW, Gawron ER, Warshaw JB 1977 Neonatal red cell superoxide dismutase enzyme levels: possible role as a cellular defense mechanism against pulmonary oxygen toxicity. Pediatr Res 11:754-757

32. Legge $M$, Brian $M$, Winterbourn $C$, Carrell $R 1977$ Red cell superoxide dismutase activity in the newborn. Aust Paediat J 13:25-28

33. Ripalda MJ, Rudolph N, Wong SL 1989 Developmental patterns of antioxidant defense mechanisms in human erythrocytes. Pediatr Res 26:366-369

34. Varga SzJ, Matkovics B, Pataki L, Molnar A, Novak Z 1985 Comparison of antioxidant red blood cell enzymes in premature and fullterm neonates. Clin Chim Acta 147:191-195

35. Strange RC, Cotton W, Fryer AA, Drew R, Bradwell AR, Marshall T, Collins MF, Bell J, Hume R 1988 Studies on the expression of $\mathrm{Cu}, \mathrm{Zn}$ superoxide dismutase in human tissues during development. Biochim Biophys Acta 964:260-265

36. Sun Y, Oberley LW, Li Y 1988 A simple method for clinical assay of superoxide dismutase. Clin Chem 34:497-500

37. Johnson MA, Murphy CL 1988 Adverse effects of high dietary iron and ascorbic acid on copper status in copper-deficient and copper-adequate rats. Am J Clin Nutr 47:96-101

38. Finley EB, Cerklewski FL 1983 Influence of ascorbic acid supplementation in copper status in young adult men. Am J Clin Nutr 37:553-556

39. Jacob RA, Skala JH, Omaye ST, Turnlund JR Effect of varying ascorbic acid intakes on copper absorption and ceruloplasmin levels of young men 1987. J Nutr 117:2109-2115

40. Crapo JD, Tierney DF 1974 Superoxide dismutase and pulmonary oxygen toxicity. Am J Physiol 226:1401-1407

41. Jansson LT, Perkkio M, Willis WT, Refino CJ, Dallman PR 1985 Red cell superoxide dismutase is increased in iron deficiency anaemia. Acta Haematol $74: 218-221$

42. Sinet PM, Couturier J, Dutrillaux B, Poissonnier M, Raoul O, Rethoré MO, Allard D, Lejeune J, Jerome H 1976 Trisomie 21 et superoxyde dismutase 1 (IPO-A). Tentative de localisation sur la sous bande 21 q22.1. Exp Cell Res $97 \cdot 47-55$

43. Baret A, Baeteman MA, Mattei JF, Michel P, Brousolle B, Giraud F 1981 Immunoreactive CUSOD and MnSOD in the circulating blood cells from normal and trisomy 21 subjects. Biochem Biophys Res Commun 98:10351043

44. Chauhan DP, Gupta PH, Nampoothiri MRN, Singhal PC, Chugh KS, Nair CR 1982 Determination of erythrocyte superoxide dismutase, catalase, glucose-6-phosphate dehydrogenase, reduced glutathione and malonyldialdehyde in uraemia. Clin Chim Acta 123:153-159

45. Castillo-Duran C, Fisberg M Valenzuela A, Egana JI, Uauy R 1983 Controlled trial of copper supplementation during the recovery from marasmus. Am $\mathbf{J}$ Clin Nutr 37:898-903

46. Uauy R, Castillo-Duran C, Fisberg M, Fernandez N, Valenzuela A 1985 Red cell superoxide dismutase activity as an index of human copper nutrition. $\mathrm{J}$ Nutr 115:1650-1655 